\title{
Meetings Between Strangers in the Nordic Bronze Age: The Evidence of Southern Swedish Rock Art
}

\author{
By Richard BRAdLEY ${ }^{1}$, COURTNeY NimurA ${ }^{2} \&$ PETER SKOGLUnd $^{3}$
}

\begin{abstract}
Recent research has established that south Scandinavia during the Nordic Bronze Age was entirely dependent on imported metal. It was obviously in contact with other parts of Europe and must have participated in a system of long-distance exchange. It is not clear how it would have operated, but it helps to explain the importance of watercraft and drawings of distinctive artefacts in the rock art on the Baltic and Atlantic coasts. A different group of images can be associated with inland areas where the art has a more restricted lexicon. Can the borderland between these traditions shed any light on the relationship between the seashore and the interior, and might this help to identify places where artefacts changed hands? This paper presents the results of fieldwork between Lakes Vänern and Vättern in Västra Götaland county, southern Sweden. It considers the character of inland rock art and whether some locations with more complex panels were used as 'aggregation sites'.
\end{abstract}

Keywords: Nordic Bronze Age, metalwork, watercraft, weapons, rock art, aggregation sites, exchange systems, cup marks, footprints

\section{THE DISTINCTIVE CHARACTER OF THE NORDIC BRONZE AGE}

The Nordic Bronze Age is one of the best-known regional traditions in prehistoric Europe, and at the same time it is among the most distinctive. The famous Swedish archaeologist Oscar Montelius (1885) investigated the associations between artefacts in Scandinavia before he took the same approach to other parts of Europe (Gräslund 1987). Despite the richness of the collections studied in Sweden, it turns out that these objects were not made from local ores (Ling et al. 2013; 2014; 2019). Although imports were reworked in a distinctive Nordic style, the metal had been introduced.

This raises questions concerning relations between the Nordic Bronze Age and its neighbours. Other features are equally distinctive. The main contacts between these regions may have been by sea rather than overland, although rivers were important in communication between the coast and the interior. At the same time the shore played an important role in long distance contacts, as Baltic amber was widely distributed in Bronze Age Europe (Vandkilde 2017; Kaul 2018).

Such links are not restricted to artefacts whose sources can be determined by scientific methods. At different times the Nordic Bronze Age shared other elements with its neighbours in North-west and Central Europe. Some have been identified by excavation and survey. Two- and three-aisled longhouses, round barrows, and round cairns are the commonest features. There were also shared beliefs, most evident through decorated metalwork featuring horses, boats, and images representing the sun. Distinctive artefacts were introduced to Scandinavia from distant areas including glass beads with the same composition as examples in Egypt and Mesopotamia (Varberg et al. 2015; 2019). There is also evidence for the adoption of distinctive practices. The use of razors, for example, may have been inspired by contacts in the Aegean (Kaul 2013). Studies of the Scandinavian evidence suggest that the importance of these elements varied over time and space.

Recent research has considered the interactions between different communities. Since people probably travelled by water, special attention is paid to maritime currents, prevailing winds, harbours, and landing places. This research has considered submarine topography, the 
configuration of the ancient coastline, and the locations of historic wrecks and portages (Vandkilde 2017, 169-72; Nimura et al. 2020). In particular, there have been studies of Bronze Age watercraft. The most useful comparisons are with the remains of seagoing vessels of Iron Age and later date (Crumlin-Pedersen \& Trakadas 2003). Earlier boats do not survive but they are represented on decorated metalwork (Kaul 1998) and many are featured in rock art. The distribution of these images covers the full extent of the Nordic Bronze Age from the north of Germany to sub-Arctic Norway (Capelle 2008; Nimura 2016).

It is obvious that non-local artefacts and products were introduced from several parts of Europe (Kristiansen \& Suchowska-Ducke 2015; Vandkilde et al. 2015; Bergerbrant 2020), but little is known about how the transactions were organised (Melheim 2018). Nor is it clear where the foreign items entered indigenous communities. That is because discussion stops at the coast. The interior of Scandinavia hardly features in these accounts. It seems as if metalwork passed through places on the Baltic and the Atlantic, only to vanish until it was deposited in graves and hoards further inland. Was it taken there by travellers who had brought it by sea, and was it acquired at other locations on the seashore? In this paper, we present the evidence of rock art in 'inland' parts of southern Sweden and highlight its contribution to this discussion. As well as the images along the coast, there are drawings of watercraft around two major lakes (see Fig. 2), suggesting that some people did move between the sea and the hinterland and that 'maritime' rock art extended into certain parts of the interior (Nimura et al. 2020). With that exception, drawings of ships and artefacts are uncommon there, although Bronze Age settlements, cairns, and metalwork are found. The cemeteries generally date from the period after about 1200 BC (Skoglund 2016).

\section{COASTAL ROCK ART IN THE NORDIC BRONZE AGE}

There are several reasons why coastal rock art can be studied in detail. Many of the panels are figurative and some depict vessels, their crews, armed men, animals, and artefacts. The drawings of ships can be compared with the designs on dated metalwork, and the objects especially axes and swords - belong to types with an accepted chronology. Another source of information is the relationship between land and water. As sea levels fell during the postglacial period, surfaces suitable for embellishment were exposed for the first time. This process must be studied on a local scale. While it cannot date the images, the method arranges them in sequence and shows that they could not have been created before a particular time. Ling's work in Uppland (Ling 2013) and Bohuslän (Ling 2014) (Fig. 1) shows that both approaches provide comparable results and that most of the rock carvings date between the Early Bronze Age and the earliest Iron Age (that is, the period between 1700 and $200 \mathrm{BC}$ ).

Coastal rock art plays an important part in studies of Bronze Age society but it can be interpreted in more than one way (Goldhahn \& Ling 2013). Drawings of weapons or warriors are not found everywhere. Boats were widely distributed and circular designs were just as common; they are usually identified with the sun and may have been carried on a ship, as the same feature is illustrated on decorated razors and on rock art (Almgren 1927, 8-14; Kaul 1998, 195-9). But it is not the only explanation. The largest vessels in coastal rock art have been compared with war canoes documented in ethnographic sources. They might have been used for raiding and long-distance trade (Horn 2018). For that reason, Ling and his colleagues (Ling et al. 2018b) postulate a series of 'seafaring chiefdoms' along the west coasts of Sweden and Norway. Because there is so much regional variation, neither explanation excludes the other. Bronze artefacts were initially shown singly or in groups along the Baltic coast but, in later panels on the Atlantic shoreline, they were associated with people engaged in combat (Ling \& Cornell 2017). The role of societies on the Scandinavian coast has been 
compared with that of Vikings during the 1st millennium AD (Kristiansen 2016; Ling et al. 2018b).

There are good reasons for emphasising contacts with distant areas. The panels portrayed artefacts which shared elements with regions as far away as Central Europe and the Mediterranean. Some claims are difficult to assess but all the metal associated with the Nordic Bronze Age must have been introduced from outside (Ling et al. 2013; 2014; 2019; Melheim et al. 2018). At the same time, it is possible to combine the economic and symbolic interpretations of maritime rock art. Perhaps the drawings interpreted as pictures of the sun evoked the visual qualities of fine metalwork. Artefacts like the solar disc from Trundholm in Denmark combined these features in the Early Bronze Age (Kaul 1998, 30-5). During the following period there was the same emphasis on boats and the sun in the Urnfield Culture (Kossack 1954).

There were significant contrasts among the rock art sites on the coast. Some panels had many components. They were of various dates and obviously developed over long periods of time. During that process certain motifs were altered and others were replaced (Milstreu 2017; Horn \& Potter 2018). Their repertoire was equally diverse. The same elements might be repeated many times - that applied to drawings of axes in Scania and pictures of boats in Bohuslän - but they could also be more diverse, featuring people, artefacts, and animals (Nimura 2016, 45-71). In the same way, a few of the decorated rocks were landmarks or seamarks but others were less conspicuous. It is clear that some locations had a special role. In south-west Uppland, the most complex compositions focused on a restricted area around Boglösa (Ling 2013). On the Atlantic coast, equally striking panels were located at intervals along the shoreline: a pattern that extended from Sweden into Norway (Coles 2005; Ling 2014). Ling (2014) relates their presence in Bohuslän to rituals undertaken at the shoreline in connection with overseas expeditions. He recognises similar practices in Uppland where communities could have met at Boglösa on special occasions (Ling 2013).

Some of the panels were on small islands and promontories but most were in more hospitable locations and few sites faced the open sea. Instead they were beside channels, estuaries, or lagoons where it would be possible to moor light craft. Here their crews could disembark and cargoes might be loaded and unloaded. Other places could have been chosen because they provided access to the hinterland. Rock art featuring ships occupied similar locations from southern Sweden to northern Norway (Kaul \& Rønne 2013; Nimura 2016, 45113). The main concentrations of images were in places that were readily accessible because of prevailing winds and currents. They could have facilitated connections with other parts of Europe (Ling et al. 2018b).

The sites with most drawings of ships and artefacts would have been suitable places for starting or concluding voyages. Here the images were unusually varied and included foreign objects, leading Ling and Uhnér (2014) to suggest a direct connection with the movement of metalwork. It was only part of a wider phenomenon. In their view, by the Late Bronze Age 'a pan-Europe ideology' connected Scandinavia into a network illustrated by representations of weapons, chariots, mirrors, and armour among other features. The same applies to religious symbols. The research has mostly focused on this coastal material, yet a different tradition of rock art was created in the Nordic Bronze Age. It is seldom discussed.

\section{INLAND ROCK ART IN THE NORDIC BRONZE AGE}

Inland rock art was widely distributed in inland parts of Sweden where it was first recognised as a distinctive tradition by Oskar Lidén in the 1930s. Through extensive fieldwork, he was able to identify a specific rock art tradition stretching from the Bjäre peninsula to central 
Västergötland. Its principal elements are cup marks, grooves, footprints, and circular motifs (Lidén 1938).

A somewhat similar tradition is also known in Denmark, where it featured in a study by Glob (1969). It shares some elements with the Swedish evidence but is more diverse; for example, circular motifs occur in a variety of different forms (Rostholm 1972). On the island of Bornholm, which is less than $50 \mathrm{~km}$ off the coast of Scania, maritime images cluster in one area, while cup marks are found much more widely (Kaul 2005, fig. 106; Nielsen 2005, fig. 130). Most inland regions in Sweden share a restricted range of motifs, but again there are regional variations among their forms and their representation on individual sites (Skoglund 2006, 16-20).

We have chosen to refer to this tradition as 'inland' rock art, although we are aware that the situation is not entirely straightforward. Bjäre is a peninsula, but the rock art is situated on elevated ground at a distance from the sea. In contrast, many Danish sites with footprints are close to the water (Glob 1969). The principal difference seems to be that most inland rock art is in landscapes suitable for cultivation and stock raising and is some distance from the coast. They may still be found close to water (lakes, rivers, and streams).

Two studies shed further light on this inland tradition. Both investigate regions in the south of Sweden. One (Skoglund 2006) is restricted to the interior of the country (Kronoberg County). The other considers the Bjäre peninsula $50 \mathrm{~km}$ to its west where rock art is more abundant. In this case it extends to the coast, but few images are found there (Nord 2009, 129-211). These regions share a number of features. There are no drawings of ships in Kronoberg County, where the commonest motifs were cup marks, grooves, rings, concentric circles, and footprints. The other project had similar results and here there were only three drawings of ships, none of which was by the sea.

These motifs have been harder to date than the drawings of ships and metalwork, but there are indications that many of them were made during the same period as other rock art. This is because they were associated with decorated cists (Jellestad Syvertsen 2002), and the more complex circular designs shared features with metal artefacts (Goldhahn 2014). They also resemble geoglyphs in the form of circles with radial lines or concentric rings, and even the internal structures of burial mounds and cairns (Hyenstrand 1969; Holst 2015). The oldest of these motifs date from the Early Bronze Age, while the most recent could not have been made much before the Iron Age - the histories of coastal and inland images overlapped (Nimura et al. 2020).

In Sweden - the focus of this paper - the most influential accounts have been of rock art close to the sea (Figs $2 \& 3$ ) but in some cases these studies included part of the interior. Forty years ago Burenhult (1980) showed that not all the components of southern Swedish rock art shared the same distribution. Drawings of ships were associated with the shoreline but other motifs extended inland. Analysis of a larger sample supports his conclusion (Nimura 2016). While simple non-figurative images could be found by the water, others occurred singly or in combination across a much wider area. The same pattern was present in every region but was most clearly evidenced on the Baltic coast of Uppland and the Atlantic coast of Bohuslän. In south-west Uppland, Coles's (2000) study gave equal weight to those in the hinterland. Here the distribution of cup marks extended well beyond the pictures of watercraft. In Bohuslän, it was more restricted but occupied a narrow zone in between the concentration of maritime images along the coast and a less productive area further inland.

Little has been written about the variations among the rock art of the interior but a few unusual examples have been studied in detail. Here there were particular concentrations of footprints, for instance at Fåglum (Burenhult 1973), or groups of wheeled vehicles (a motif typically found in coastal locations) like those at Frännarp (Coles 2002). Where information is available, there seems to have been a preference for prominent outcrops or boulders with 
images towards their highest point (Nord 2009, 206). They included sites where the top of the stone would have been difficult to access. In several instances, fires were lit there, although it is not known when that happened. Decorated rocks of this kind featured more motifs than less conspicuous surfaces nearby.

As evident from our fieldwork, there are further contrasts in the representation of pecked motifs. The commonest elements were cup marks, but they show a surprising diversity (Fig. 4). Their frequency varied from a few examples to several hundred and they might be clustered in groups or scattered across the rock. Similarly, they could be of different sizes and depths and might be organised in lines, grids, or joined together by grooves. Individual examples were lengthened to form oval motifs which could represent feet and pairs of cupules were linked to resemble dumbbells. Others were enclosed by a ring. In the more complex panels, they were accompanied by specialised designs: concentric circles, wheel crosses, and footprints organised in pairs. Such variations have attracted less attention than the differences among the sites on the coast. As a result, their importance has been underestimated.

If coastal rock art poses problems, the same is true of its inland counterpart. The circular images - especially the ring cross - might have represented the sun; this interpretation is favoured when they occur by the sea. In the same way, the pairs of footprints shared a distinctive alignment and nearly all of them were directed towards the solar arc; on most sites they were absent between the north-west and the north-east where the sun could not be seen (Skoglund et al. 2017). Perhaps they marked the positions in which people stood during ceremonies.

\section{RELATIONSHIPS BETWEEN COASTAL AND INLAND ROCK ART}

Many writers have suggested that the rock art on the coast was related to travel by sea and the processes by which non-local artefacts and ideas came into the Nordic Bronze Age. The relationship cannot have been straightforward, as Malmer (1981) pointed out, the greatest density of images does not correspond with the principal finds of metalwork. More attention should be paid to inland areas whose archaeology is often less considered. If these traditions of rock art were made in separate regions, they could have been the work of different communities.

This need not imply that there were separate maritime and inland cultures, as both regions operated within a larger Nordic framework, but they were associated with different visual traditions. Earlier studies have shown how maritime rock art can be used in discussions of exchange. Could a similar approach be applied to the rock art of the interior? Can we use our observations on these traditions of rock art to discuss how people who lived there were involved in the movement of metals? Where was material exchanged? And how did they engage with trade networks that extended to the coast and across the sea?

The following discussion is in two parts. The first documents the relationship between these different traditions of rock art on a local level and the second considers the relationship between the people who made them.

\section{Compositions}

There is a striking contrast between the two main areas with rock art in Sweden. In Bohuslän the distributions of typically 'inland' and typically 'coastal' motifs overlap in a narrow strip of productive land (Coles 2005; Ling 2014). Elements belonging to each tradition are found together, and the repertoire of maritime images is supplemented by cup marks, wheel crosses, footprints, and drawings of carts. Some depictions of watercraft appear in isolation but features associated with both traditions can be combined in the same panel. They may be superimposed but there is nothing to suggest an overall sequence. 
The evidence is different in Uppland where the distribution of inland rock art is much more extensive (Coles 2000; Ling 2013). Here both traditions can be represented at different locations. The principal sites with non-figurative imagery were in a separate area from most of the drawings of ships. On the other hand, both groups came close to the Bronze Age coast. The style that extended further inland is represented by cup marks, which can be supplemented by oval motifs, dumbbells, grooves, wheel crosses, concentric circles, and footprints. Ships were represented close to the sea and were usually associated with other images; the region contained a few exceptionally large vessels. Many of the biggest panels drew on both traditions so that groups of watercraft were depicted on the same surfaces as the other designs. In contrast to the evidence from Bohuslän there is little evidence that they were superimposed.

In Uppland there are panels in which cup marks were scattered amongst the depictions of boats but this is comparatively unusual and, more often, elements associated with both traditions occupied different parts of the same panel or separate areas of the rock, leaving empty spaces between (Fig. 5). A single outcrop might feature several clusters of pecked motifs, and it seems to have been important to distinguish between the features of these two traditions. It was usual for cup marks and related motifs to occupy the highest part of the rock but that was not always the case. The significant element is that in different ways the components of inland rock art were separated from maritime imagery.

\section{Interpretations of coastal and inland rock art}

There is every reason to believe that access to imported metalwork played a significant part in establishing and maintaining social distinctions within the Bronze Age population. Settlement sites can include timber buildings over $50 \mathrm{~m}$ in length and a few burials are associated with artefacts of exceptional quality. Although there are sites where bronze artefacts were made, there is virtually no direct evidence to show where the material was obtained. Lene Melheim (2018) recognises this problem in a recent paper in which she identifies just two candidates in south Scandinavia: a cemetery at Hunn in Norway, and a settlement at Hallunda close to Lake Malaren in Sweden. Both produced striking evidence of metallurgy and each was located in a region with a notable concentration of rock art. Are there any other ways of determining where imported objects were exchanged?

Melheim and Ling (2017) have also discussed the role of Bronze Age 'aggregation sites'. The term refers to gatherings of dispersed communities that take place on special occasions and at defined locations where they can be accompanied by rituals. In ancient Europe such sites are claimed because they contain concentrations of non-local artefacts, or because isotopic evidence shows that animals were introduced from distant areas (Madgwick et al. 2019). Conkey's (1980) influential study of Upper Palaeolithic sites in northern Spain took a different approach. She drew on visual culture and characterised a series of sites where dispersed groups of hunter-gatherers might have come together. These locations featured artefacts decorated in styles associated with different regions (although more recent work suggests that chronological differences were also significant; Lillios 2020, 81). In some ways, Fahlander $(2012 ; 2018)$ takes a comparable approach when he argues that the 'hybrid' character of some panels in Uppland identifies places used as middle ground by people of different origins.

Might Conkey's (1980) approach shed light on both styles of rock art in south Scandinavia: the maritime imagery found by the sea, and the non-figurative images that extended across inland areas? One of the most striking characteristics of Bronze Age sites on the coast is that they were accessible from the hinterland. Another is that they could combine features taken from both traditions but did so in distinctive ways. How were they related to one another? 
One possibility is that the two traditions of rock art were juxtaposed at places where different communities met. They might have been among the locations where artefacts changed hands and may have been where those objects first entered local communities. If so, it is easier to envisage the missing component of an exchange system that is most evident on the coast. But there is a problem. The argument cannot be conclusive since it depends on studies of regions with an exceptional number of petroglyphs. Their repertoire is unusually varied and for that reason they might not typify the situation in the Nordic Bronze Age as a whole. The relationship between the two traditions of rock art must be worked out by comparing the well-known images on the coast with their counterparts in inland areas. The potential of this method can be demonstrated by distribution maps but it has rarely been followed by investigations on the ground.

One way to achieve a better balance is to consider a sample of sites extending from the heart of the country along a transect leading towards the water. To avoid emphasising the unusual situation in Uppland and Bohuslän, this study includes the shores of two enormous lakes associated with images like those by the sea. Having considered the juxtaposition of the two styles on the east and west coasts of Sweden, is there similar patterning from the middle of the country? If so, how should it be interpreted?

\section{A NEW CASE STUDY}

This section focuses on the inland rock art found in between Lake Vänern to the west and Lake Vättern to the east (Figs 1 \& 2). The sample consisted of 24 sites with cup marks, footprints, grooves, ovals, or rings (of which 17 were intact and accessible; Appx 1). An earlier project investigated another 20 sites on or close to the water and these are considered again here (Nimura et al. 2020). The new study extended inland for a distance of $100 \mathrm{~km}$.

By combining the information from both projects, more than 40 decorated rocks can be considered. Those away from the lakes were selected according to two criteria. Most were chosen because they possessed more than one of the characteristics of inland sites - normally, cup marks and footprints. They had to be reasonably abundant to make them easier to identify on surfaces that had often been damaged or obscured. It was important to consider which kinds of rock were used for making images - were they boulders or outcrops and were they higher or more conspicuous than the undecorated rocks in the vicinity? Did any of them command long distance views? The motifs were even more important. How much variation existed between different sites? This question could only be investigated on the ground as the written descriptions of these designs were not always consistent; that was especially true when they referred to 'footprints' and 'foot soles'. Details of all the inland locations appear in the appendix to this article and those around both lakes are catalogued in another paper (Nimura et al. 2020).

There were variations among the inland sites but most could be explained by the local geology. Boulders - generally erratics - were more commonly selected towards the south, while outcrops were preferred further to the north and were usually larger. The rocks that were selected were more conspicuous than the others in the vicinity and some were rounded or flat-topped (Fig. 6). There was an obvious preference for rocks containing exposures of quartz (Fig. 7). The pecked motifs were usually towards the highest point but could extend down the sides. Apart from boulders, these sites commanded extended views over tracts of fertile soil, small lakes, and areas of wetland.

The quality of the panels varied between different areas. Those towards the south were rough and coarse-grained but further to the north the stone was smoother and would have been easier to work. To some extent this distinction was mirrored by the images themselves. Cup marks were represented throughout the study area but the character of the pecked footprints changed from site to site. Sometimes they were elongated hollows, 
identified as footprints only because they were organised in pairs, but where the rock was fine grained, they were executed with more precision. The frequency of motifs changed from site to site. Cup marks outnumbered the remaining features. Some were significantly larger than the others on the same panel; at the locations examined in the field the smallest quantity was nine, and the greatest was 222 . Just as cup marks could be made in extraordinary numbers, the same applied to pairs of footprints (Fig. 8). In this case their frequency was between two and 25 .

These features were very different from those around the shores of Lake Vänern and Lake Vättern, which are linked to the Atlantic and the Baltic respectively. Their archaeology was studied in detail in an earlier paper but several features are relevant here. Few of the rocks were particularly conspicuous. They were usually located close to harbours which are in use today. With only a few exceptions, the rock art had a restricted number of components and any one panel included a limited variety of motifs. New elements were rarely superimposed on older ones. Compared with the exceptional evidence from Uppland and Bohuslän, most of the panels were simple and understated. Like their inland counterparts, nearly all the panels featured cup marks - their frequency extended from one to over $300-$ and footprints occurred at a third of the locations. Ships were represented at $70 \%$ of the sites, where they were depicted together with humans, animals, axes, and wheel crosses. The mixture of elements resembles the rock art on the coast, but on a more limited scale (Nimura et al. 2020).

How does this evidence compare to the observations made in other regions? There are three aspects to the question.

The first concerns the rock art of inland areas. It became clear that certain surfaces were chosen at the expense of others, with an emphasis on the most conspicuous rock in any one location. The choice was emphasised because the motifs were usually located on its highest point. This finding was consistent with that of earlier studies but a more striking outcome of the survey was to show that the range of pecked motifs was strikingly similar to that observed in other inland regions. The only obvious variations could be related to the character of the surfaces themselves. It was justifiable to consider these motifs as a single tradition.

A second issue was the presence of a different group of images around the margins of major lakes. They were more restrained than their counterparts on the coast but they featured most of the same elements. One of the problems of analysing maritime rock art in Uppland and Bohuslän was deciding how it was related to the shoreline when it was made. Sea levels have changed considerably since the Bronze Age in these areas and there is evidence that this process had an impact during that period. Fortunately, similar processes hardly affected the lakes considered here. On one level they resemble the sea - they can be difficult to cross in adverse conditions and large parts are out of sight of land - but the shoreline has scarcely changed since the art was made (SGU 2018). It is obvious that the distribution of rock art focused on the sites of modern harbours where it would have been possible to land boats in the Bronze Age. On the coast changes of sea level are well documented but the positions of landing places have to be inferred.

Thirdly, it became clear that some of the panels associated with inland lakes had the same repertoire as those on the Atlantic and Baltic coasts. Again, they featured images whose distribution did not extend far from the water's edge. Others combined the same elements with the rock art of the interior. That relationship extended in only one direction, for the distinctive images that characterise the coastal rock art hardly impinged on the distribution of the other tradition, which remained almost entirely distinct.

There are two important exceptions that should be discussed. 


\section{Husaby and Högsbyn}

Two distinctive sites are withdrawn from the sea and set back from the shore of Lake Vänern. Both are well known for their distinctive imagery, but they have not often been considered in their wider setting. About $5 \mathrm{~km}$ from Lake Vänern is Husaby (Fig. 9), where seven decorated panels extend along a flat exposure of good quality rock. This location may have attracted attention because natural hollows in the stone resembled the outlines of boats (Hauptman Wahlgren 1998). The prehistoric images are distributed in groups separated from one another by areas in which motifs are largely or completely absent. They are extraordinarily diverse.

Two of these vignettes are dominated by images shared with inland regions - a dumbbell and a wheel cross in one case; in another, two clusters of cup marks accompanied by wheel crosses and a single ship. Others show greater variation. The most prolific panel features cup marks, axes, pairs of foot soles, vessels, and wheel crosses; and another one includes footprints, wheel crosses, cup marks, 'snakes', and people with weapons. Every concentration has its distinctive repertoire, and there is no indication of any overall scheme. Most of the motifs occur in other parts of the same region, but the drawings of feet include examples that strongly resemble the pattern further to the south; the same applies to the dumbbells.

The same observation applies to the famous complex at Högsbyn (Fig. 10). This site is located beside a body of water $12 \mathrm{~km}$ beyond the opposite side of Lake Vänern (Svensson 1982; Andersson 2000). In this case, the panels are further apart and occupy a series of outcrops extending over a distance of $700 \mathrm{~m}$. Previous studies have considered the distribution of different images and their relationships with one another. The most elaborate compositions are towards each end of the site - on higher ground towards the north and at the water's edge to the south. They include many images of boats. Wheel crosses are commoner towards the shoreline, and foot soles towards the opposite extreme. Cup marks and drawings of feet are more frequent in the area between them, and there are numerous human figures. On a more local level some of the designs divide into smaller zones, with concentrations of ships, on the one hand, and footprints, 'snakes', wheel crosses, and cup marks, on the other (Tilley 1999, 33-73). Elements associated with each style of rock art are combined on some of the surfaces, and on others they are kept apart.

The significance of both sites is considered in the final part of this paper.

\section{PERSPECTIVES FROM THE COAST AND THE INTERIOR}

The Nordic Bronze Age was distinctive in several ways. As its name suggests, it was a regional phenomenon, yet its very existence depended on connections with a wider area. Even when artefacts were made in local forms their raw material had been introduced from other parts of Europe. Although the sources of the metal may have changed over time, the distinctive geography of Scandinavia means that most, or all, of it would have been introduced by sea. That can be shown by characterisation studies. The roles of other elements have to be inferred, that is why their interpretation is less straightforward, but there are good reasons for suggesting that systems of belief were widely shared. Thus, the early depictions in the north can be compared with the images on the Wismar Horn and the Nebra Sky Disc in Germany (Kristiansen \& Larsson 2005, 195-6; Meller 2013). Both were decorated in a Nordic style.

More ambitious reconstructions depend on ethnographic analogy. If valuable items were introduced by sea, boat crews or those who organised the expeditions may have had a special status. That is why Ling and his colleagues postulate a series of 'seafaring chiefdoms' with connections in Denmark, Sweden, Norway, and further afield (Ling \& Cornell 2017; Ling et al. 2018a; 2018b). The mechanisms by which commodities were acquired by the local inhabitants have received less attention. The present writers have suggested links between the Baltic, the Atlantic, and a series of harbours around two large inland lakes where 
there are panels of rock art with ships. Evidence from the historical period shows that journeys inland from the coast would have been perfectly feasible (Nimura et al. 2020), but it remains to establish where imported materials changed hands. The same applies to any local products that passed in the opposite direction.

It is here that rock art has a part to play. This paper has argued that it was made in two distinct but overlapping traditions in southern Sweden, one associated with the sea and the other with the interior of the country. Such contrasts extended beyond their characteristic imagery. The tradition associated with inland areas is found near fertile ground suitable for settlements and food production but it is more difficult to link complex panels of maritime imagery with domestic contexts close by, and here the main sites are beside sheltered inlets where it would have been safe to moor boats. However arcane these images, the people who made them seem to have been influenced by practical considerations and such locations could have been used by travellers. There is no evidence to show whether they lived on the coast. Perhaps the drawings of ships and metalwork recorded these voyages and their outcome.

For the most part inland and maritime images have separate distributions. While those associated with the hinterland can be also identified on the coast, the opposite is seldom the case (Fig. 2). There are few drawings of ships away from the sea and the largest inland lakes and rivers. The relationship between both groups of motifs is particularly striking where they are present in the same region. Although features of each tradition could be combined, as happened in Bohuslän, that was not always the case, and where the two groups featured on a particular rock (and even in a particular panel) they could be separated from one another. Perhaps they did not share the same significance. If the images of boats commemorated contacts by sea, did the other designs record the presence of people who lived in the interior? Exchanges are often conducted at neutral locations, free from the constraints imposed by mutual suspicion (Dening 2004; Mack 2011, chap. 5; Haour 2013).

Was this happening in south Scandinavia? It seems the most parsimonious explanation for the locations of Husaby and Högsbyn. Here the elements of inland and coastal rock art came together in a particularly distinctive manner. Both sites feature a whole series of decorated rocks and panels in which these features were combined, but the groups of images were located some distance from one another, and every combination of motifs was idiosyncratic. More important, both places were set apart from the wider distribution of petroglyphs. They were secluded locations where different communities might have encountered one another and come to terms. There are indications that similar sites exist elsewhere in south Scandinavia, but it is not clear how often they occur. They call for targeted research, but that requires another project. This investigation has shown that they need to be studied in their local contexts and must be investigated on the ground.

\section{SUMMARY}

This study discussed two distinctive traditions of rock art that existed in Bronze Age southern Sweden, but the images along the Atlantic and Baltic shorelines have attracted most attention. This analysis suggests that the places where both traditions overlapped could have included aggregation sites at which imported artefacts changed hands. Although these objects were usually carried by sea, such places were not restricted to the coast and can also be recognised in the interior where their features are particularly distinctive. Discussions of an exchange system that focus exclusively on maritime rock art have investigated a biased sample and need to be complemented by new work in the hinterland.

Acknowledgements: The fieldwork described in this paper was supported by the Lennart J. Hägglunds stiftelse för arkeologisk forskning och utbildning. 


\section{BIBLIOGRAPHY}

Almgren, O. 1927. Hällristningar och kultbruk: bidrag till belysning av de nordiska bronsåldersristningarnas innebörd. Stockholm: Wahlström \& Widstrand

Andersson, T. 2000. Hällristningar från Högsbyn. Hällristningsrapport 1. Högsbyn: Ask \& Embla

Bergerbrant, S. 2020. Wool textiles in the early Nordic Bronze Age: Local or traded? In S. Sabatini \& S. Bergerbrant (eds), The Textile Revolution in Bronze Age Europe: Production, specialisation, consumption, 255-73. Cambridge: Cambridge University Press

Burenhult, G. 1973. The Rock Carvings of Götaland, Part 2. Lund: Acta Archaeologica Lundensia

Burenhult, G. 1980. The Rock Carvings of Götaland, Part I. Stockholm: Stockholm University Institute of Archaeology

Capelle, T. 2008. Bilderwelten der Bronzezeit: Felsbilder in Norddeutschland und Skandinavien. Mainz am Rhein: Philipp von Zabern

Coles, J. 2000. Patterns in a Rocky Land: Rock carvings in south-west Uppland, Sweden. Uppsala: Department of Archaeology \& Ancient History

Coles, J. 2002. Chariots of the gods? Landscape and imagery at Frännarp, Sweden. Proceedings of the Prehistoric Society 68, 215-46

Coles, J. 2005. Shadows of a Northern Past: Rock carvings of Bohuslän and Østfold. Oxford: Oxbow Books

Conkey, M. 1980. The identification of prehistoric hunter-gatherer aggregation sites: The case of Altamira. Current Anthropology 21(5), 609-30

Crumlin-Pedersen, O. \& Trakadas, A. (eds). 2003. Hjortspring: A Pre-Roman Iron-Age warship in context. Roskilde: The Viking Ship Museum in Roskilde

Dening, G. 2004. Beach Crossings: Voyaging across times, cultures and self. Philadelphia, PA: University of Pennsylvania Press

Dolfini, A., Crellin, R.J., Horn, C. \& Uckelmann, M. (eds), Prehistoric Warfare and Violence: Quantitative and qualitative approaches. New York: Springer

Fahlander, F. 2012. Articulating hybridity: Structurating situations and indexical events in North-European rock art. In N.M. Burström \& F. Fahlander (eds), Matters of Scale: Processes and courses of events in the past and the present, 53-73. Stockholm: Institutionen för arkeologi och antikens kultur, Stockholms universitet

Fahlander, F. 2018. Bildbruk i mellanrum: Mälarvikens hällbilder under andra årtusendet fvt. Stockholm: Institutionen för arkeologi och antikens kultur, Stockholms universitet

Fokkens, H. \& Harding, A. (eds). 2013. The Oxford Handbook of the European Bronze Age. Oxford: Oxford University Press

Glob, P. 1969. Helleristninger i Danmark. Copenhagen: Nordisk forlag

Goldhahn, J. 2014. Engraved biographies - rock art and life-histories of Bronze Age objects. Current Swedish Archaeology 22, 97-136

Goldhahn, J. \& Ling, J. 2013. Bronze Age rock art in Northern Europe. In Fokkens \& Harding (eds) 2013, 270-90

Gräslund, B. 1987. The Birth of Prehistoric Chronology. Cambridge: Cambridge University Press

Haour, A. 2013. Outsiders and Strangers. Oxford: Oxford University Press

Hauptman Wahlgren, K. 1998. Encultured rocks: Encounter with a ritual world of the Bronze Age. Current Swedish Archaeology 6, 85-97

Holst, M.K. 2015. Bronze Age geometry and cosmology. In M. Holst \& M. Rasmussen (eds), Skelhøj and the Bronze Age Barrows of Southern Scandinavia, vol. 2, 53-89. Højberg: Jysk Arkeologisk Salskap 
Horn, C. 2018. Fast like a war canoe: Pragmamorphism in Scandinavian rock art. In Dolfini et al. (eds) 2018, 109-27

Horn, C. \& Potter, R. 2018. Transforming the rocks - time and rock art in Bohuslän, Sweden. European Journal of Archaeology 21, 361-84

Hyenstrand, Å. 1969. Gravformer och symboltecken under yngre bronsålder. Fornvännen 63, $185-89$

Jellestad Syvertsen, K. 2002. Ristninger i graver - graver med ristninger. In J. Goldhahn (ed.), Bilder av Bronsålder, 151-83. Stockholm: Almqvist \& Wiksell

Kaul, F. 1998. Ships on Bronzes. Copenhagen: National Museum of Denmark

Kaul, F. 2005. Helleristningerne i landskabet. In Kaul et al. (eds) 2005, 95-99

Kaul, F. 2013. The Nordic razor and the Mycenaean lifestyle. Antiquity 87, 461-72

Kaul, F. 2018. Middle Bronze Age long distance exchange: Early glass, amber and guestfriendship, Xenia. In B. Nessel, D. Neumann \& M. Bartelheim (eds), Bronzezeitlicher Transport, Akteure, Mittel und Wege, 189-211. Tübingen: Ressourcenkulturen Band 8

Kaul, F. \& Rønne, P. 2013. Bronzes, farms and rock art: The agrarian expansion of North Norway. Adoranten 2013, 25-56

Kaul, F., Stolze, M., Nielsen, F.O. \& Milstreu, G. (eds). 2005. Helleristninger. Billeder fra Bornholms bronzealder. Rønne: Bornholms Museum

Kjellén, E. 1930. En nyupptäckt hällristning i Västergötland. Fornvännen 25, 252-3

Kossack, G. 1954. Studien zum Symbolgut der Urnenfelder und Hallstattzeit Mitteleuropas. Berlin: De Gruyter

Kristiansen, K. 2016. Bronze Age Vikings? A comparative analysis of deep historical structures and their dynamics. In L. Melheim, Z.T. Glørstad \& H. Glørstad (eds), Comparative Perspectives on Past Colonisation, Maritime Interaction and Cultural Integration, 177-86. Sheffield: New Directions in Anthropological Archaeology

Kristiansen, K. \& Larsson, T. 2005. The Rise of Bronze Age Society: Travels, transmissions and transformations. Cambridge: Cambridge University Press

Kristiansen, K. \& Suchowska-Ducke, P. 2015. Connected histories: The dynamics of Bronze Age interaction and trade 1500-1100 BC. Proceedings of the Prehistoric Society 81, 361-92

Lidén, O. 1938. Hällgröpningsstudier $i$ anslutning till nya sydsvenska fynd. Lund: Gleerupska universitetsbokhandeln

Lillios, K. 2020. The Archaeology of the Iberian Peninsula. Cambridge: Cambridge University Press

Ling, J. 2013. Rock Art and Seascapes in Uppland. Oxford: Oxbow Books

Ling, J. 2014. Elevated Rock Art: Towards a maritime understanding of Bronze Age rock art in Northern Bohuslän, Sweden. Oxford: Oxbow Books

Ling, J. \& Cornell, P. 2017. Violence, warriors and rock art in Bronze Age Scandinavia. In R. Chacon \& R. Mendoza (eds), Feast, Famine and Fighting? Multiple pathways to social complexity, 15-33. New York: Springer

Ling, J. \& Uhnér, C. 2014. Rock art and metal trade. Adoranten 2014, 23-43

Ling, J., Chacon, R. \& Chacon, Y. 2018a. Rock art, secret societies, long-distance exchange, and warfare in Bronze Age Scandinavia. In Dolfini et al. (eds) 2018, 149-74

Ling, J., Earle, T. \& Kristiansen, K. 2018b. Maritime mode of production: Raiding and trading in seafaring chiefdoms. Current Anthropology 59, 488-524

Ling, J., Hjärthner-Holdar, E., Grandin, L., Billström, K. \& Persson, P.-O. 2013. Moving metals or indigenous mining? Provenancing Scandinavian Bronze Age artefacts by lead isotopes and trace elements. Journal of Archaeological Science 40, 291-304 
Ling, J., Hjärthner-Holdar, E., Grandin, L., Stos-Gale, Z., Kristiansen, K., Melheim, L., Artioli, G., Angelini, I., Krause, R. \& Canovaro, C. 2019. Moving metals IV: Swords, metal sources and trade networks in Bronze Age Europe. Journal of Archaeological Science: Reports 101839

Ling, J., Stos-Gale, Z., Grandin, L., Billström, K., Hjärthner-Holdar, E. \& Persson, P.-O. 2014. Moving metals II: Provenancing Scandinavian Bronze Age artefacts by lead isotope and elemental analyses. Journal of Archaeological Science 41, 106-32

Mack, J. 2011. The Sea: A cultural history. London: Reaktion Books

Madgwick, R., Grimes, V., Lamb, A., Nederbragt, A., Evans, J. \& McCormick, F. 2019. Feasting and mobility in Iron Age Ireland: Multi-isotope analysis reveals the vast catchment of Navan Fort, Ulster. Nature Scientific Reports 9, 19792

Malmer, M. 1981. A Chorological Study of North European Rock Art. Stockholm: Almqvist \& Wiksell

Melheim, L. 2018. Weight units and the transformation of value: Approaching premonetary currency systems in the Nordic Bronze Age. In D. Brandherm, E. Heymans \& D. Hofmann (eds), Gifts, Goods and Money: Comparing currency and circulation systems in past societies, 67-83. Oxford: Archaeopress

Melheim, L. \& Ling, J. 2017. Taking the stranger on board - The two maritime legacies of Bronze Age rock art. In P. Skoglund, J. Ling \& U. Bertilsson (eds), North Meets South: Theoretical aspects on the northern and southern rock art traditions in Scandinavia, 59-86. Oxford: Oxbow Books

Melheim, L., Grandin, L., Persson, P-O., Billström, K., Stos-Gale, Z., Ling, J., Williams, A., Angelini, A., Canovaro, C., Hjärthner-Holdar, E. \& Kristiansen, K. 2018. Moving metals III: Possible origins for copper in Bronze Age Denmark based on lead isotopes and geochemistry. Journal of Archaeological Science 96, 85-105

Meller, H. 2013. The sky disc of Nebra. In Fokkens \& Harding (eds) 2013, 266-9

Milstreu, G. 2017. Recut rock art images (with a special emphasis on ship carvings). In S. Bergerbrant \& A. Wessman (eds), New Perspectives on the Bronze Age, 281-7. Oxford: Archaeopress

Montelius, O. 1885. Om tidsbestämning inom bronsåldern med särskildt afseende på Skandinavien. Stockholm: Kongl. Vitterhets-, historie- och antiquitetsakademien

Nielsen, F.O. 2005. Bornholm i yngre bronzealder. In Kaul et al. (eds) 2005, 112-33

Nimura, C. 2016. Prehistoric Rock Art in Scandinavia: Agency and environmental change. Oxford: Oxbow Books

Nimura, C., Bradley, R. \& Skoglund, P. 2020. Navigating inland: Bronze Age watercraft and the lakes of Southern Sweden. European Journal of Archaeology 23(2), 186-206

Nord, J. 2009. Changing Landscapes and Persistent Places: An exploration of the Bjäre Peninsula. Lund: Department of Archaeology \& Ancient History, University of Lund

Rostholm, H. 1972. Danske helleristninger og deres forhold til de ovrige nordiske helleristninger fra bronzealderen. Holstebro Museums Årskrift 1971-72, 20-47

Schnittger, B. 1911. En hällristning i Västergötland. Fornvännen 6, 196-203

SGU (Geological Survey of Sweden/Sveriges geologiska undersökning). 2018. Shore-level Map Generator [online]. Available at: https://www.sgu.se/en/products/maps/mapgenerator/ [Accessed 18 June 2019]

Skoglund, P. 2006. Hällristningar i Kronobergs Län. Lund: Department of Archaeology \& Ancient History, University of Lund

Skoglund, P. 2016. Rock Art Through Time: Scanian rock carvings in the Bronze Age and earliest Iron Age. Oxford: Oxbow Books

Skoglund, P., Nimura, C. \& Bradley, R. 2017. Interpretations of footprints in the Bronze Age rock art of South Scandinavia. Proceedings of the Prehistoric Society 83, 289-303 
Svensson, K.R. 1982. Hällrisrningar $i$ Älvsborg län. Uddevalla: Älvsborg lansmuseum Tilley, C. 1999. Metaphor and Material Culture. Oxford: Blackwell

Vandkilde, H. 2017. The Metal Hoard from Pile in Scania, Sweden. Aarhus: Aarhus University Press

Vandkilde, H., Hansen, S., Kotsakis, K., Kristiansen, K., Müller, J., Sofaer, J., Stig Sørensen, M.L. 2015. Cultural mobility in Bronze Age Europe. In P. Suchowska-Ducke, S. Scott Reiter \& H. Vandkilde (eds), Forging Identities: The mobility of culture in Bronze Age Europe, 5-37. Oxford: British Archaeological Report S2771

Varberg, J., Gratuze, B. \& Kaul, F. 2015. Between Egypt, Mesopotamia and Scandinavia. Late Bronze Age glass beads found in Denmark. Journal of Archaeological Science $54,168-81$

Varberg, J., Kaul F. \& Gratuze, B. 2019. Bronze Age glass and amber: Evidence of Bronze Age long distance exchange. Adoranten 2019, 5-29

APPENDIX 1. ROCK ART SITES (IN ALPHABETICAL ORDER) THAT WERE VISITED DURING FIELDWORK IN 2019; THEIR SWEDISH NATIONAL HERITAGE BOARD NUMBERS (RIKSANTIKVARIEÄMBETET, RA ̈̈); THE MOTIFS REPRESENTED; \& DESCRIPTIONS OF THE MOTIFS, OTHER OBSERVATIONS, \& LANDSCAPE CONTEXTS

\section{FIGURES}

Fig. 1. Map of southern Sweden showing areas; places mentioned in the text: (a) Boglösa 138:1, (b) Litslena 242:1-2, (c) Brastad 1:1; and sites listed in Appendix 1

Fig. 2. Map of southern Sweden showing the locations of rock art sites, watercraft motifs, and sites listed in Appendix 1

Fig. 3. Brastad 1:1 in Bohuslän showing a range of 'typical coastal' rock art motifs in combination with motifs also found inland. Image ID: 3914, created by Lasse Bengtsson; (C) Svenskt Hällristnings Forsknings Arkiv (Swedish Rock Art Research Archives)

Fig. 4. (a) Timmele 113:1 with 222 cupmarks and 4 foot soles; (b) Länghem 222:1 with 22 cupmarks, 10 foot soles, and 1 'groove shape'; (c) Hällstad 92:1 with 155 cupmarks, 10 foot soles, and 1 cup-and-ring (photographs: C. Nimura)

Fig. 5. Litslena 242:1-2 in Uppland. This panel is near a larger outcrop and is split in two parts on either side of a ridge: (1) about 2-3 watercraft, 8-12 foot soles, and approximately 100 cupmarks; (2) about 4-5 watercraft and 10 cupmarks (after Coles 2000, fig. 86)

Fig. 6. The flat-topped rock outcrop at Södra Ving 166:1, the top of which has 130 cupmarks and 10 foot soles (photograph: C. Nimura)

Fig. 7. An edge of the rock at Länghem 236:1, showing quartz, the top of which has 10 cupmarks and 2 foot soles (photograph: C. Nimura)

Fig. 8. Part of the long, flat rock outcrop of Fåglum 5:1, showing the high quantity of paired foot soles (photograph: C. Nimura)

Fig. 9. Husaby 70:1: (a) panel section with a 'snake' motif, footprints and foot soles, watercraft, wheel crosses, cup marks, and a ship-shaped depression that fills with water after rain; (b) panel section with a 'groove shape' that resembles a foot sole, a vessel with a large ring, wheel cross, and cup marks in specific patterns; (c) panel section with a small vessel, two 'dumbbells', and a cup mark (photographs: C. Nimura) 
Fig. 10. Högsbyn: (a) panel showing 'snake' motifs, footprints, and cup marks; (b) a small panel of ships right at the lake's edge; (c) a small outcrop covered in cup marks in linear patterns; (d) a group of humans 'on land' and 'acrobats' on a vessel (photographs: C. Nimura)

${ }^{1}$ Department of Archaeology, University of Reading, Whiteknights Box 227, Reading RG6 6AB, UK. Email: r.j.bradley@ reading.ac.uk

${ }^{2}$ Institute of Archaeology, University of Oxford, 34-36 Beaumont St, Oxford OX1 2PG, UK. Email: courtney.nimura@arch.ox.ac.uk

${ }^{3}$ Department of Cultural Sciences: Archaeology, Linnaeus University, 39182 Kalmar, Sweden. Email: peter.m.skoglund@lnu.se

Corresponding author: courtney.nimura@ arch.ox.ac.uk

Running header

R. Bradley et al. MEETINGS BETWEEN STRANGERS IN THE NORDIC BRONZE AGE: S. SWEDISH ROCK ART 


\begin{tabular}{lll}
\hline $\begin{array}{l}\text { Map } \\
\text { no. }\end{array}$ & RAÄ number & Motifs (alphabetical) \\
\hline 6 & Bjärka 7:4 & $\begin{array}{l}15 \text { cupmarks, 10 foot } \\
\text { soles }\end{array}$
\end{tabular}

9 Böne 35:1 102 cupmarks, 16 foot soles

The stones $(c .0 .55 \times 0.45 \mathrm{~m} ; 0.9 \times 0.45 \mathrm{~m})$ had been moved \& were no longer in situ. The foot soles are paired \& very deeply pecked. The original description in Fornsök states that the stones came from the nearby burial ground at Ekornavallen, less than $3 \mathrm{~km}$ from Hornborgasjön (lake).

The outcrop (c. $2.5 \times 2.5 \mathrm{~m}$, WNW-ESE) is located on a farm at the edge of arable \& in an elevated position ( $280 \mathrm{~m}$ above sea level) which overlooks the flat ground around it. It is currently located less than $1 \mathrm{~km}$ from the Ätran (river) \& may have been $c .0 .5 \mathrm{~km}$ from the edge of small lake in $c .1050 \mathrm{cal}$ BC (SGU 2018). The foot soles are paired \& point down the gently sloping, relatively smooth panel. Above the line of paired foot soles, there is a collection of cupmarks arranged in a rectangular shape. Not all foot soles or cup marks could be identified due to overgrowth.

to overgrowth.
The outcrop $(c .15 \times 5 \mathrm{~m}, \mathrm{E}-\mathrm{W})$ is on the edge of a road between fields with a $360^{\circ}$ view of a wide $\&$ flat landscape. The north-flowing Nossan (river) currently runs around it $\&$ is $c .1 .3 \mathrm{~km}$ at its nearest point. It may have been even closer in $c .1050$ cal BC (SGU 2018). The outcrop is long \& flat \& covered in mostly paired foot soles. Some are quite deeply pecked \& paired with cup marks, a pattern identified at other sites. Further references: Schnittger 1911; Malmer 1981, 61, no. 14437.

The outcrop is long \& tall (c. $2.3 \times 1.1 \mathrm{~m}, \mathrm{NE}-\mathrm{SW})$. It overlooks a wide landscape (210 $\mathrm{m}$ asl) \& is less than $2 \mathrm{~km}$ from a small lake (Björken); it may have been nearer in $c .1050 \mathrm{cal}$ BC (SGU 2018). The panel is at the top of the outcrop on the side with the better-quality rock, although the rock as a whole is not very smooth. The outcrop has long striations running perpendicular to the length of the rock. The cup marks are visible \& cover the panel, some of them organised in lines, as identified at other sites. There is one deeply pecked cup-and-ring, which interacts with a foot sole. The feet are mostly single examples, with one potential pair, although they are all very difficult to identify.

5 animals ('snakes'),

(Flyhov)

349 cupmarks, 1 cupand-ring, 19 footprints/3 foot soles, 5 grooveshapes, 5 humans, 13 indefinable, 2 nets, 1 other definable, 5 rings, 1 half-ring, 28 ships, 1 spiral, 32 sun crosses (1 oval-shaped), 5 


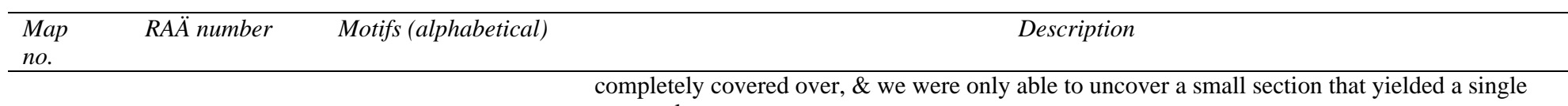

14 Länghem 222:1 22 cupmarks, 10 foot soles, 1 groove shape

Länghem 236:1 10 cupmarks, 2 foot soles

6) 1 cupmark

\section{cup mark.}

The boulder $(4 \times 2.2 \mathrm{~m}, \mathrm{~N}-\mathrm{S})$ is located in the middle of an uncleared field in an area with many small lakes (c. 2-3 km nearby). It may have been as close as $1.5 \mathrm{~km}$ to a small lake in $c .1050 \mathrm{cal}$ BC (SGU 2018). The boulder is prominent in the partially cleared field, slightly sloping, \& with a poor quality surface. The cup marks were identifiable but the 'foot soles' were very vague $\&$ more similar to what are described as 'ovals' or 'groove-shaped depressions' in other areas. 2 cup marks were very deeply pecked, up to $4 \mathrm{~cm}$ deep.

The outcrop is on a small piece of land situated between two lakes (Torpasjön \& Ytrre Åsunden). The rock outcrop is $c .100 \mathrm{~m}$ from both water bodies and may have been even nearer in $c .1050$ cal BC (SGU 2018). The outcrop consists of two main blocks $(9 \times 4$ m, WNW-ESE; $2.5 \times 3.5 \mathrm{~m}$ NW-SE) that had split from one; both are tall \& steeply \& and are on top of a slight mound. The motifs are said to be clustered at the top of 1 outcrop but only a few small, oval-shaped 'footprints' \& cup marks could be identified.

The boulder $(1.5 \times 0.8 \mathrm{~m}, \mathrm{WNW}-\mathrm{ESE})$ is currently located at the boundary of a wooded area $\&$ arable land, c. $1 \mathrm{~km}$ from Torpasjön (lake). It may have been on the edge of this lake in $c .1050$ cal BC (SGU 2018). The boulder is slightly sloping \& the surface is of fairly poor quality. It affords a good view of the landscape. It has significant quartz veins running along its side $\&$ a couple of the cup marks were large $\&$ deeply pecked (up to $1.5 \mathrm{~cm}$ deep). 2 cup marks were connected to each other. The 'foot soles' were identifiable but less defined (more oval-shaped) than in other regions.

The boulder $(0.3 \times 0.3 \mathrm{~m}, \mathrm{NNE}-\mathrm{SSW})$ is currently located in a wooded area on top of a small hill, less than $200 \mathrm{~m}$ from the edge of Yttre Åsunden (lake) \& may have been less than $50 \mathrm{~m}$ from the lake in $c .1050 \mathrm{cal} \mathrm{BC}$ (SGU 2018). The boulder, the most prominent in the area, is slightly sloping \& has two parallel feet on top. The 'foot soles' are a regular size, around 21-22 $\mathrm{cm}$ long and 6-8 $\mathrm{cm}$ wide, but less defined (more oval-shaped) than in other regions. Nearby, there is another boulder with 5 cup marks (Länghem 238:1).

The site was destroyed by road works, although a prominent outcrop still exists as part of a ridge next to the road between two fields. It would have been part of a $100 \mathrm{~m}$ long ridge located next to small river less than $15 \mathrm{~km}$ from Lake Vänern. It may have been less than $300 \mathrm{~m}$ from a small body of water in $c .1050 \mathrm{cal} \mathrm{BC}$ (SGU 2018). From the top of the ridge, there is a $360^{\circ}$ view that stretches into the distance.

The outcrop is extensive \& slopes down toward a field. It is currently less than $600 \mathrm{~m}$ from a significant river (105 m asl), which is part of a lake network that is navigable as far as Bohuslän. It may have been even closer to this river in $c .1050$ cal BC (SGU 2018). We were unable to locate the panels, though in some sections uncovered the rock was very smooth \& flat. From the outcrop, one can see into the distance. 


\begin{tabular}{|c|c|c|c|}
\hline $\begin{array}{l}\text { Map } \\
\text { no. }\end{array}$ & RÄ̈ number & Motifs (alphabetical) & Description \\
\hline 5 & Skärv 117:1 & $\begin{array}{l}9 \text { cupmarks, } 7 \text { foot } \\
\text { soles, } 1 \text { groove shape }\end{array}$ & $\begin{array}{l}\text { The outcrop is located in the middle of a field \& contains a small panel }(1.0 \times 0.5 \mathrm{~m}, \mathrm{~N}-\mathrm{S}) \\
\text { around which the farmer has built a clearance cairn. It is located } c .1 .2 \mathrm{~km} \text { from a small lake } \\
\text { (Bysjön) }(150 \mathrm{~m} \text { asl }) \text { and may have been a similar distance in } c .1050 \mathrm{cal} \text { BC (SGU } 2018) \text {. The } \\
\text { motifs are deeply pecked }(0.5-1 \mathrm{~cm} \text { deep) and include } 3 \text { sets of paired feet \& a single foot sole as } \\
\text { well as deeply-pecked cup marks }(0.5-2 \mathrm{~cm} \text { deep). The cup marks form a line at the top of the } \\
\text { panel. }\end{array}$ \\
\hline 11 & Södra Ving 12:1 & $\begin{array}{l}100 \text { cupmarks, } 10 \text { foot } \\
\text { soles }\end{array}$ & $\begin{array}{l}\text { The steeply sloping outcrop }(5 \times 3 \mathrm{~m} \text {, NW-SE) is the largest part of a long }(c .70 \mathrm{~m}) \text {, uncleared } \\
\text { ridge on the edge of a field. It is less than } 50 \mathrm{~m} \text { from the river Viskan }(190 \mathrm{~m} \text { asl), which flows } \\
\text { into the Kattegat Sea. It may have been on the edge of lake Mogden in } c .1050 \mathrm{cal} \text { BC (SGU } \\
2018 \text { ). Some of the cup marks ( } 1-3 \mathrm{~cm} \text { deep) \& 'foot soles' were deeply pecked (1-2 cm deep). } \\
\text { The foot soles are oval \& some of the cup marks had been pecked into quartz veins. }\end{array}$ \\
\hline 10 & $\begin{array}{l}\text { Södra Ving } \\
166: 1\end{array}$ & $\begin{array}{l}130 \text { cupmarks, } 10 \text { foot } \\
\text { soles }\end{array}$ & $\begin{array}{l}\text { The long outcrop }(7 \times 4 \mathrm{~m}, \mathrm{NE}-\mathrm{SW}) \text { is currently located less than } 300 \mathrm{~m} \text { from a small lake } \\
\text { (Örsjö) }(205 \mathrm{~m} \text { asl }) \text { that is connected to the river Viskan, which flows into the Kattegat Sea. It } \\
\text { may have been less than } 200 \mathrm{~m} \text { from the lake in } c .1050 \mathrm{cal} \text { BC (SGU 2018). The domed outcrop } \\
\text { has a fairly smooth surface in some areas \& is the only outcrop remaining in an otherwise } \\
\text { cleared field. The motifs are all clustered on the top of the outcrop. Some of the cup marks are } \\
\text { very deeply pecked }(0.05-2 \mathrm{~cm} \text { deep) \& others seem to form lines that run parallel along the } \\
\text { outcrop. The foot soles are oval \& not all are clearly defined. }\end{array}$ \\
\hline 12 & Timmele 113:1 & $\begin{array}{l}222 \text { cupmarks, } 4 \text { foot } \\
\text { soles }\end{array}$ & $\begin{array}{l}\text { The small outcrop }(2.3 \times 2.5 \mathrm{~m}, \mathrm{NW}-\mathrm{SE}) \text { is currently located less than } 500 \mathrm{~m} \text { from the river } \\
\text { Ätran }(180 \mathrm{~m} \text { asl), a } 240 \mathrm{~km} \text { long river which flows out to the Kattegat Sea, \& next to a small } \\
\text { tributary (Ryssabäcken). It may have been even nearer to the Ätran in } c .1050 \mathrm{cal} \text { BC (SGU } \\
\text { 2018). A distinct panel slopes in } 1 \text { direction \& is covered in } 222 \mathrm{cup} \text { marks, some of which are } \\
\text { very deeply pecked }(0.5-4 \mathrm{~cm} \text { deep). At least two cup marks form the 'heel' of } 2 \text { feet. }\end{array}$ \\
\hline 13 & $\begin{array}{l}\text { Ulricehamn } \\
34: 2\end{array}$ & $\begin{array}{l}46 \text { cupmarks, } 21 \text { foot } \\
\text { soles, } 1 \text { other defineable }\end{array}$ & $\begin{array}{l}\text { The panel }(5 \times 1.5 \mathrm{~m}, \mathrm{NW}-\mathrm{SE}) \text { is part of an outcrop on a hill }(190 \mathrm{~m} \text { asl) at the edge of a forest, } \\
\text { which commands a good view of the surrounding landscape. It is currently located less than } 500 \\
\mathrm{~m} \text { from the river Brunnsbäcken, which feeds into lake Assunden }(1.2 \mathrm{~km} \text { from the site). It may } \\
\text { have been a similar distance from both in } c .1050 \mathrm{cal} \text { BC (SGU } 2018) \text {. The site is part of an } \\
\text { extensive burial ground of around } 50 \text { Iron Age burials (Ulricehamn } 34: 1) \text {. We were unable to } \\
\text { uncover the motifs due to overgrowth on the outcrop. }\end{array}$ \\
\hline
\end{tabular}

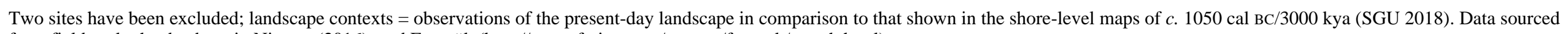
from fieldwork, the database in Nimura (2016), and Fornsök (http://www.fmis.raa.se/cocoon/fornsok/search.html) 